\title{
ON THE HYDRORHIZA AND CLASPERS OF THE HYDROID MYRIOTHELA COCKSI (VIGURS)
}

\author{
By S. M. Manton, M.A., Sc.D. (Mrs J. P. Harding) \\ Fellow of Girton College \\ From the Zoological Laboratory, Cambridge, and the British Museum (Natural History)
}

(Text-figs. I-2)

THE HYDRORHIZA

The types of hydrorhiza shown by the northern hemisphere species of the hydroid Myriothela have been described by Bonnevie (I899) as follows:

I

Lamellary, expanded with chitinous perisarc

M. cocksi
II

Tentacle-like, attaching filaments which grow from the base of the hydranth

M. phrygia M. verrucosa

\section{III}

Root-like point with fine attaching filaments, IO-20 mm. long

M. gigantea

M. minuta

M. mitra

Among the southern hemisphere species the first type appears to be represented by $M$. harrisoni and the second by $M$. australis, M. penola, M. capensis, etc. Further details concerning M. cocksi were given by Hinks (I868), "the adherent base massive, of a dark horn colour, sending out a few tubular and root-like prolongations"; a small figure is also given, but it shows little detail of the form of the hydrorhiza where it is attached to the substratum. Allman (I875) describes and figures "short sucker-like processes of attachment" arising from the hydrorhiza which lies at right angles to the rest of the polyp.

During a recent examination of some southern hemisphere species of Myriothela particular attention has been paid to the manner of attachment of the hydrorhiza to the substratum in those species which show the second type of hydrorhiza (Manton, 1940). Since little is known of the structure and manner of attachment of the hydrorhiza of the first and third types referred to above, an examination of $M$. cocksi has been made with a view to remedying in part this deficiency. I am indebted to the Marine Biological Association for supplying me with well fixed material of $M$. cocksi, and to Dr L. E. R. Picken for carrying out chitin analyses.

The only other species which appears to show the first type of hydrorhiza mentioned above is the Australian M. harrisoni, where the cylindrical hydrorhiza "gives off slender rooting processes, expanded and truncated distally, for attachment to the substratum" (Briggs, 1928).

The lower portion of a young expanded specimen of $M$. cocksi is shown in 
Fig. I $a$; the substratum bas been removed from the hydroid. The hydrorhiza is roughly cylindrical in shape, but distorted to fit the irregularities of the substratum. The basal four-fifths of the hydrorhiza is encased in perisarc of a brown colour. The perisarc, unlike that of many hydroids, is everywhere adherent to the surface of the underlying ectoderm; it is fairly rigid, and its presence immobilizes this part of the hydroid. The perisarc is about $6 \mu$ thick. It stains red with Mallory's triple stain and black with iron haematoxylin. It is composed of true chitin. The dark colour probably indicates that the perisarc is hardened by impregnation, as is the cuticle of insects (Pryor, 1940 $a, b$ ).

Towards the blastostyle zone the perisarc becomes thinner, losing its staining reactions, and merges into the thin cuticle which covers the ectoderm of the hydranth. This cuticle is well shown in microphotographs of an allied species (Manton, I940, pl. III, figs. 23 and 25). The zone covered by perisarc is shown by the mechanical tint in Fig. I $a$.

Below the blastostyle-bearing zone the axis of the hydrorhiza bears thirteen adhesive tentacles (a.t.) attached to the substratum and covered by perisarc. They are of various lengths up to $\mathrm{I} \cdot 25 \mathrm{~mm}$. One unattached tentacle arises above the zone covered by perisarc (u.a.t.), and is invested only by cuticle. Just above this lies the rudiment of another adhesive tentacle (r.a.t.), identified as such by sectioning.

The adhesion of the hydrorhiza to the substratum is effected only by the perisarc covering the flattened extremities of the adhesive tentacles (a.d.), and the perisarc here appears browner and thicker than elsewhere.

It is probable that growth of the hydrorhiza zone takes place orally, since young adhesive tentacles are found only at the oral unstiffened end of the hydrorhiza. In the region where the perisarc merges into the general cuticle the development of ectodermal musculature in the main axis is more complex than in other parts of the hydroid where these fibres form a regular longitudinal layer. Here the muscle processes lie in a variety of planes forming a network through the inner part of the ectoderm. It is possible that this musculature, besides controlling the position of the upper part of the hydroid, may be used to form local distortions in the flexible upper part of the hydrorhiza so as to produce contact between the young unstiffened adhesive tentacles and the substratum. The subsequent chitinization, thickening and hardening of the cuticle will then fix these distortions. The hydrorhiza figured here is young and simple, but the contorted hydrorhiza of gnarled appearance which is common on old specimens may have grown in this way.

In structure the unattached adhesive tentacle differs little from those of M. penola and M. capensis (Manton, I940, text-figs. 6, 7). The tentacle is hollow, its enteric cavity opening directly into the main enteron. The ectoderm of the stem resembles that of other parts of the body and is provided with nematocysts. The terminal ectoderm forms a regular layer of darkly staining narrow cells, and nematocysts are almost absent. These cells do not contain 


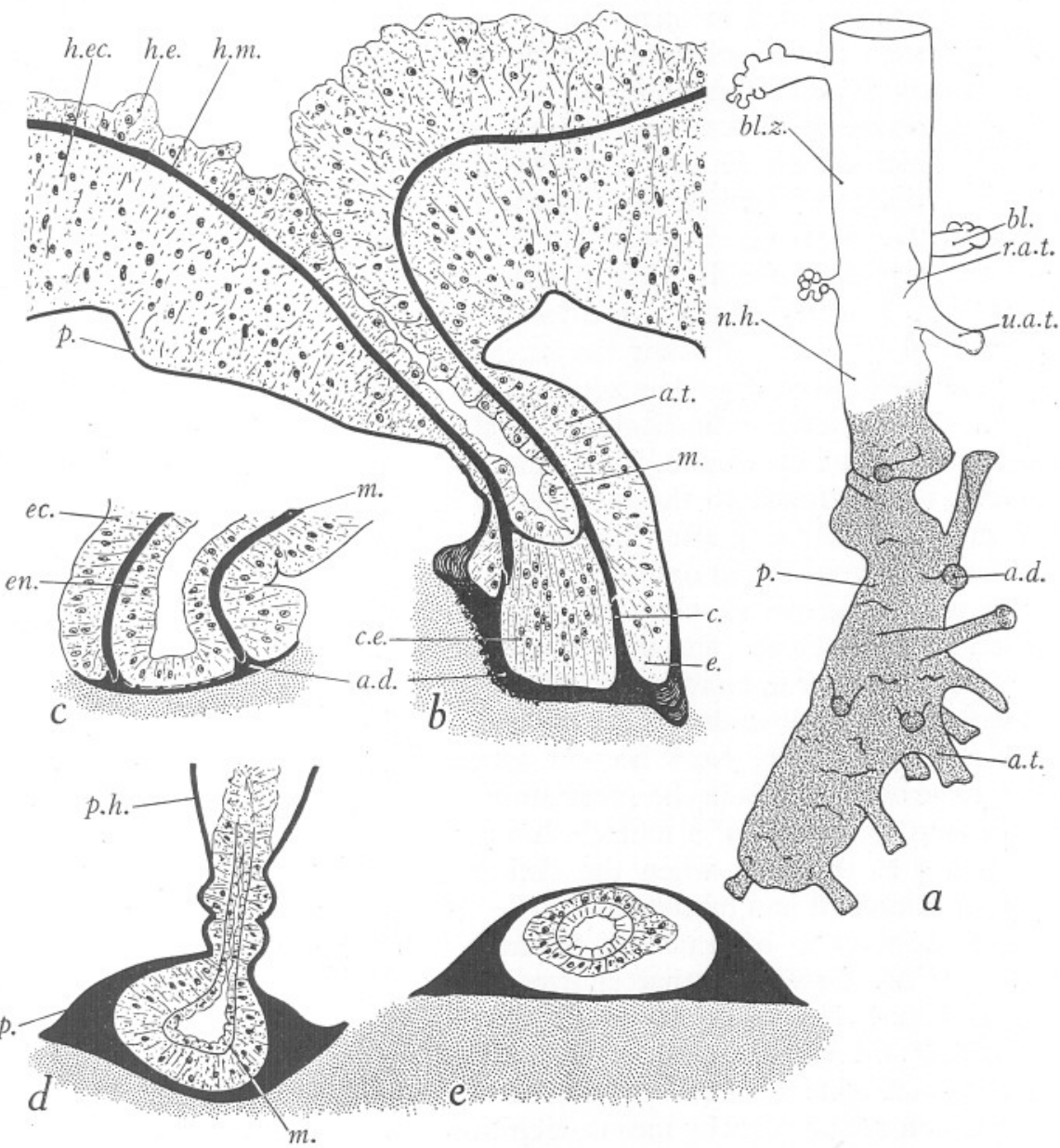

Fig. I. $a$, the basal part of a young specimen of $M$. cocksi. The mechanical tint represents that part of the hydrorhiza which is covered by perisarc. $b$, sagittal section through an attached hydrorhiza tentacle and wall of the hydrorhiza of $M$. cocksi. The substratum is indicated by mechanical tint. c, sagittal section through an attached hydrorhiza tentacle of $M$. capensis. The substratum is indicated by mechanical tint. $d$, vertical section through the junction of hydrocaulus and hydrorhiza of Obelia. e, transverse section through a hydrorhiza stolon on Obelia.

$a, \times$ I2 approx.; $b-e, \times$ IIO approx.

a.d., adhesive disk of chitin attached to substratum. a.t., adhesive tentacle of hydrorhiza. $b l$., blastostyle. bl.z., blastostyle-bearing zone of hydroid. c., annular flange of chitin passing inwards from adhesive disk to unite with mesogloea. c.e., central part of terminal ectoderm. e., lateral part of terminal ectoderm. ec., ectoderm. en., endoderm. h.e., hydrorhiza endoderm. h.ec., hydrorhiza ectoderm. h.m., hydrorhiza mesogloea. $m$., mesogloea. n.h., part of hydrorhiza not yet covered by perisarc. p., perisarc. p.h., perisarc of hydrocaulus. r.a.t., rudiment of adhesive tentacle. u.a.t., unattached adhesive tentacle. 
the intracellular granules, which are present in the two above-named species, and are there destined to form the chitinoid layer. The mesogloea is thick along the stem of the adhesive tentacle, but becomes very thin distally, and here appears to be perforated in places.

The structure of an attached adhesive tentacle is shown in Fig. I $b$. The perisarc which covers the axis of the hydrorhiza and the stem of the tentacle is greatly thickened against the substratum. In this particular tentacle the terminal attachment fits into a hollow in the substratum and is humped, but most adhesive disks are flat. The perisarc is particularly thick round the rim of the disk. Just within this rim a deep annular flange of chitin projects into the terminal ectoderm, dividing the latter into a central (c.e.) and a lateral (e.) part. The mesogloea layer is prolonged into a thick rim projecting into the ectoderm to meet the chitinoid flange, as shown in the sagittal section figured, and the two structures unite. The adherent disk of chitin at the end of the tentacle is thus linked to the mesogloea. The junction between mesogloea and chitin is clearly seen after Mallory's triple stain, as the former stains blue and the latter from red to orange.

The perisarc shows no obvious structure other than a slight stratification parallel with the surface, and in sections it tends to split into upper and lower layers which appear to be identical. The chitin covering the tip of an adherent tentacle shows some slight colour difference from the rest. After Mallory's triple stain the deeper parts become orange red, and the superficial layers which have been torn from the substratum appear a purplish red. The process of adhesion by the tip of a tentacle has not been seen, but presumably this takes place at the time when the cuticle covering an unattached tentacle becomes thickened and hardened.

There appears to be much in common between the type of hydrorhiza shown by $M$. cocksi and that shown by $M$. phrygia, M. capensis, etc., a similarity not indicated by the literature. The second type, seen in $M$. capensis and M. penola, has been described by Manton (1940). Both types of hydrorhiza adhere to the substratum by the tips of tentacular structures, the adhesion taking place by means of chitinoid material which is also attached to the mesogloea. A sagittal section of an attached adhesive tentacle of $M$. capensis is shown in Fig. I $c$. In species showing this type of hydrorhiza a perisarc is usually described as absent, but it is in fact reduced to the small disk capping the bare adhesive tentacle (Fig. I $c, a . d$.). The naked hydrorhiza of such species is often very short, so that the adhesive tentacles tend to arise close together from the base of the hydranth, instead of at intervals from an elongated axis.

The general perisarc of $M$. cocksi must give some support to the points of adhesion with the substratum, and with the absence of the investing perisarc from species showing the second type of hydrorhiza a stronger attachment of the chitin to the mesogloea is seen. The mode of union between chitin and mesogloea described for $M$. cocksi (Fig. I $b$ ) is clearly repeated by $M$. capensis 
(Fig. I c). The annular flange of chitin (Fig. I $b, c$.) in $M$. cocksi does not project inwards so far in $M$. capensis. The central portion of ectoderm (c.e.), which remains intact in $M$. cocksi, has disappeared in $M$. capensis, these cells breaking down during the formation of the chitinoid disk and leaving the latter closely adherent to the mesogloea right across the tip of the tentacle (Fig. I c). In $M$. penola, a giant species $850 \mathrm{~mm}$. long, the large adhesive tentacles show a more extensive dove-tailing of the chitinous material into the mesogloea, a feature correlated with the greater size and greater strength needed per unit area of attaching surface.

It has been shown (Manton, I940) that the chitinoid disks of M. capensis and $M$. penola are formed from granules of intracellular material situated in the terminal ectodermal cells, and the bases of these cells in M. penola extensively perforate the mesogloea. With the breakdown of these cells and the fusion of their granules chitinoid disks are formed which are thus anchored into the mesogloea. This method of formation of a chitinoid layer is not seen in $M$. cocksi, where intracellular granules are absent and the epithelium persists after chitinization of the cuticle. It is probable that the very unusual method shown by $M$. capensis and $M$. penola is associated with the extreme reduction in the extent of the perisarc, and the necessity for the remaining disk to be correspondingly strongly united with the soft parts of the hydroid. This method of chitin formation may be expected to occur in other species showing this type of hydrorhiza.

The hydrorhiza of many simple hydroids shows no elaboration for attachment such as is seen in Myriothela. Obelia, for example, possesses a very simple type of hydrorhiza consisting of extensive stolons lying over the substratum and attached to it along their adjacent surfaces. Sections of the hydrorhiza of Obelia are given for comparison with Myriothela. In Fig. I $d$ a section is shown which passes longitudinally through the base of the hydrocaulus where it joins the hydrorhiza, and Fig. I $e$ shows a transverse section of a stolon some distance from the hydrocaulus. Adhesion to the substratum takes place by the perisarc only, and no part of the coenosarc is involved. The perisarc is flattened against the substratum and is thickened along the outer edges of the stolon. The ectoderm may remain in contact with the perisarc, as in Fig. I $d$, but the coenosarc shrinks away from the perisarc in many regions situated remote from the hydrocaulus or from the growing tip of the stolon. The mesogloea $(m$. $)$ is very thin and is unconnected with the perisarc (compare Fig. I $d$ with I $b$ and I $c$ ).

The perisarc of the hydrorhiza of Obelia is thick, but it is not stiff or hard as is that of Myriothela. It stains blue with Mallory's triple stain, and is composed of almost pure unhardened chitin. In these hydroids the pure chitin is flexible and pale in colour, just as is the unimpregnated unhardened cuticle in insects (Pryor, I940 $a, b$ ). 


\section{METHOD OF GROWTH OF THE HYDRoID}

It has been shown (Manton, I940) that in M. penola increase in size of the polyp takes place from definite growth zones. The tentacle-bearing region elongates mainly from the oral end, and the blastostyle-bearing zone grows orally at the expense of the basal part of the tentacle-bearing zone. The same method of growth is shown by $M$. cocksi, young tentacles are formed round the mouth, and a young specimen shows immature blastostyles arising on the lower part of the tentacle-bearing zone before the tentacles are all absorbed. The hydrorhiza in both species grows in length at its oral end (see above).

\section{The Claspers}

The "claspers" of $M$. cocksi have for long been regarded as remarkable or unique structures. Many new species of Myriothela have been described recently, but none shows this feature. The appearance and function of the claspers in $M$. cocksi in carrying the fertilized and developing ova has been described by Allman (1875), Benoit (1925), and others. The claspers are tentacle-like structures arising from or near the bases of the blastostyles, and the eggs are carried on their extremities, several claspers often adhering to one egg membrane.

A slight overlapping of the hydrorhiza and blastostyle-bearing zones has been described in $M$. penola and $M$. phrygia, where some of the adhesive tentacles of the hydrorhiza arise from or near the bases of a few of the proximal blastostyles (Manton, I940). The adhesive tentacles in this position bear a striking superficial resemblance to the claspers of $M$. cocksi. Moreover, inspection shows that the method of adhesion of the claspers to the egg of M. cocksi differs little from that of a hydrorhiza tentacle to its substratum.

An unattached clasper in structure resembles a free hydrorhiza tentacle in that the ectodermal and endodermal epithelia are complete, the mesogloea at the tip is thinner, denser, and more darkly staining with Mallory's triple stain, and is here perforated by the bases of some of the ectodermal cells. The tip of a clasper first adheres to the egg membrane by the surface of its ectodermal cells (see Benoit, I925, text-figs. 24-26), the ectodermal epithelium being intact. Further changes in the clasper are not described by Benoit, but he figures an older clasper with only one layer of cells at its tip (Benoit, I925, text-figs. 27-28), a feature also shown by Korotneff (I888, pl. 2, fig. IO). A sagittal section through an attached clasper which is older still is shown here in Fig. 2. The mesogloea at the tip has thickened, particularly at the margin of the adhesion, and has united directly with the egg membrane. The ectoderm at the tip of the clasper has disappeared. The only difference between the adhesion of the clasper and that of a hydrorhiza tentacle of $M$. capensis or $M$. penola is the absence of a chitinous disk of adhesion in the former; in both a mesogloea attachment is made and the terminal ectoderm has disappeared (compare Figs. I $c, 2$ ). 
Thus the similarity between (i) the position of the claspers of $M$. cocksi and some of the hydrorhiza tentacles of $M$. penola and $M$. phrygia, and (ii) the structure and method of adhesion of the claspers of $M$. cocksi and the hydrorhiza tentacles of other species of Myriothela, suggests that the claspers represent a specialized part of the hydrorhiza which has altered its function and now adheres to ova instead of to the substratum.

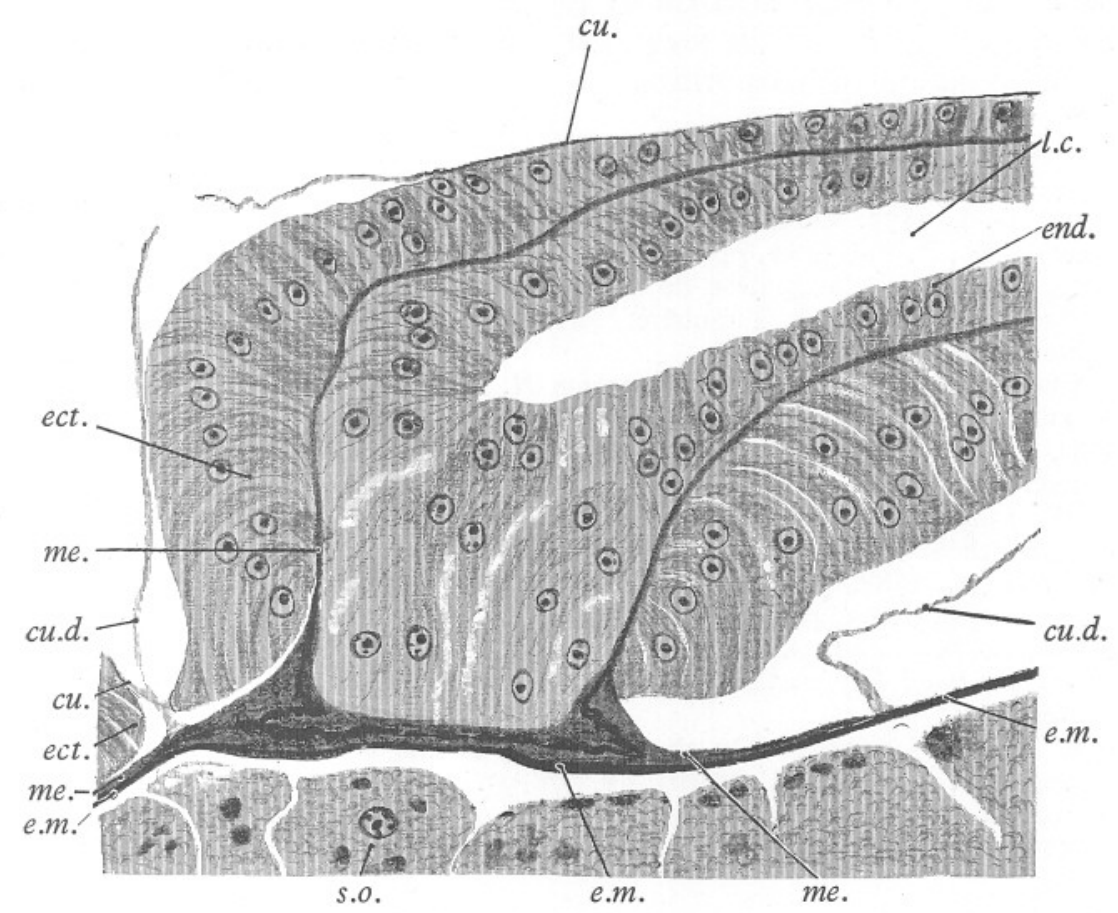

Fig. 2. Section passing sagittally through a clasper and part of the ovum to which it is attached in $M$. cocksi. The edge of a second clasper is seen on the left. The cuticle of the clasper is raised from the epithelium in places (cu.d.) owing to shrinkage of the tissues since death. The mesogloea of the clasper is clearly united with the egg membrane, the terminal ectoderm having disappeared.

$c u$., cuticle. cu.d., cuticle detached from epithelium by shrinkage. ect., ectoderm. e.m., egg membrane. end., endoderm. l.c., endodermal lumen of clasper. me., mesogloea. s.o., segmenting ovum.

\section{SUMMARY}

The hydrorhiza of Myriothela cocksi is described. It bears adhesive tentacles covered by perisarc, which adhere to the substratum by their flattened extremities.

The chitin forming a disk of adhesion is thick, and is attached to the mesogloea of the tentacle. The terminal ectoderm persists. 
The hydrorhiza of $M$. cocksi and of species such as M. capensis, M. penola, and $M$. phrygia, etc., is built on a common plan. In the latter species the perisarc is reduced to adhesive disks more firmly attached to the mesogloea.

The method of growth of $M$. cocksi is recorded.

The structure and method of attachment of the claspers of M. cocksi to the egg membrane is described. The mesogloea at the tip of the clasper fuses with the egg membrane after the disappearance of the terminal ectoderm.

Evidence is given for the view that the claspers of $M$. cocksi represent a specialized part of the hydrorhiza.

\section{REFERENCES}

Allman, G. J., I875. On the structure and development of Myriothela. Phil. Trans. Roy. Soc., B, Vol. CLXv, pp. 549-76, pls. 55-8.

BenoIT, P., I925. L'ovogenèse de les premiers stades du développement chez la Myriothèle et chez la Tubulaire. Arch. Zool. exp. gén., Vol. LXII, pp. 85-326 (Io pls., 65 text-figs.).

Bonnevie, K., I899. Hydroida. Norwegian N. Atlant. Exp., I876-1878, Zool., Vol. XXvi, pp. I-IO3 (8 pls., 3 text-figs.).

BRIGgS, E. A., I928. Studies on Australian Athecate Hydroids. No. I. Two new species of the genus Myriothela. Rec. Austr. Mus. Sydney, Vol. xvi, pp. 305-I5 (pls. 33-4, I text-fig.).

Hrnks, T., I868. British Hydroid Zoophytes. London, pp. I-338, pls. I-67.

KorotnefF, A., I888. Contribution à l'étude des Hydraires. Arch. Zool. exp. gén., Vol. vI, pp. 2I-3I, pls. I-2.

Manton, S. M., 1940. On two new species of the Hydroid Myriothela. British Graham Land Exp. 1934-1937, Scient. Rep., Vol. I, No. 4, pp. 255-94 (4 pls., 9 text-figs.).

PRYoR, M. G. M., I940a. On the hardening of the ootheca of Blatta orientalis. Proc. Roy. Soc., B, Vol. cxxviII, pp. 378-93.

- I940 b. On the hardening of the cuticle of Insects. Proc. Roy. Soc., B, Vol. cxxvIII, pp. 393-407 (I pl.). 